medRxiv preprint doi: https://doi.org/10.1101/2020.05.10.20049783; this version posted May 15, 2020. The copyright holder for this preprint (which was not certified by peer review) is the author/funder, who has granted medRxiv a license to display the preprint in perpetuity.

It is made available under a CC-BY-NC 4.0 International license.

\title{
1 Attributable mortality of vancomycin resistance in ampicillin-resistant Enterococcus \\ 2 faecium bacteremia in Denmark and the Netherlands: a matched cohort study
}

3 Wouter C. Rottier ${ }^{1}$, Mette Pinholt ${ }^{3,4^{*}}$, Akke K. van der Bij ${ }^{5, a^{\star}}$, Magnus Arpi ${ }^{6}$, Sybrandus N. Blank ${ }^{7}$, 4 Marrigje H. Nabuurs-Franssen ${ }^{8}$, Gijs J.H.M. Ruijs ${ }^{9}$, Matthijs Tersmette ${ }^{10}$, Jacobus M. Ossewaarde ${ }^{11}$, 5 Rolf H. Groenwold ${ }^{12}$, Henrik Westh ${ }^{3,4}$ and Marc J.M. Bonten ${ }^{1,2}$, on behalf of the Dutch VRE

6 Bacteremia Investigators and the Danish Collaborative Bacteraemia Network (DACOBAN)

$7 \quad{ }^{1}$ Julius Center for Health Sciences and Primary Care, and ${ }^{2}$ Department of Medical Microbiology, University

8 Medical Center Utrecht, Utrecht, the Netherlands

$9{ }^{3}$ Department of Clinical Microbiology, Hvidovre University Hospital, Hvidovre, Denmark

$10{ }^{4}$ Faculty of Health and Medical Sciences, University of Copenhagen, Copenhagen, Denmark

$11{ }^{5}$ Centre for Infectious Disease Control (CIb), National Institute for Public Health and the Environment

12 (RIVM), Bilthoven, the Netherlands

$13{ }^{6}$ Department of Clinical Microbiology, Herlev University Hospital, Herlev, Denmark

$14{ }^{7}$ Department of Internal Medicine, Maxima Medical Center, Eindhoven/Veldhoven, the Netherlands

$15{ }^{8}$ Department of Medical Microbiology, Canisius-Wilhelmina Hospital, Nijmegen, the Netherlands

$16{ }^{9}$ Laboratory for Clinical Microbiology and Infectious Diseases, Isala, Zwolle, the Netherlands

$17{ }^{10}$ Department of Medical Microbiology and Immunology, St. Antonius Hospital, Utrecht/Nieuwegein;

$18{ }^{11}$ Department of Medical Microbiology, Maasstad Ziekenhuis, Rotterdam, The Netherlands

$19{ }^{12}$ Department of Clinical Epidemiology, Leiden University Medical Center, Leiden, The Netherlands.

20 a Present affiliation: Department of Medical Microbiology and Immunology, Diakonessenhuis, Utrecht, the 21 Netherlands.

22 * Authors contributed equally.

\section{Corresponding author:}

24 Wouter C. Rottier

25 Julius Center for Health Sciences and Primary Care

26 University Medical Center Utrecht

27 Huispostnummer STR 6.131

28 Postbus 85500

293508 GA Utrecht

30 the Netherlands.

31 Telephone: +31887557676

32 Fax: +31887568099

33 E-mail: w.c.rottier-2@umcutrecht.nl 
medRxiv preprint doi: https://doi.org/10.1101/2020.05.10.20049783; this version posted May 15, 2020. The copyright holder for this preprint (which was not certified by peer review) is the author/funder, who has granted medRxiv a license to display the preprint in perpetuity.

It is made available under a CC-BY-NC 4.0 International license.

\section{Abstract}

35 Background In many European hospitals, ampicillin-resistant Enterococcus faecium (ARE) is

36 endemic, while outbreaks of vancomycin-resistant $E$. faecium (VRE), belonging to the same

37 genetic lineage, are increasingly reported. We studied the attributable mortality due to

38 vancomycin resistance in patients with $E$. faecium bacteremia and evaluated whether this is

39 mediated by a delay in appropriate antibiotic therapy.

40 Methods In a retrospective matched cohort study, patients with VRE bacteremia occurring

41 between 2009 and 2014 in 20 Dutch and Danish hospitals were matched to patients with ARE

42 bacteremia, on hospital, ward, length of hospital stay prior to bacteremia, and age. The risk ratio

43 (RR) for 30-day mortality contrasting VRE with ARE was estimated with further analytic control

44 for confounding factors.

45 Results In all, 63 VRE and 234 ARE episodes were matched (36 and 130 for the Netherlands and

4627 and 104 for Denmark). Crude 30-day mortality was 27\% and 38\% for ARE in the Netherlands

47 and Denmark, respectively, and 33\% and $48 \%$ for VRE in the respective countries. The adjusted

48 RR for 30-day mortality for VRE was 1.54 (95\% confidence interval (CI) 1.06-2.25). Although

49 appropriate therapy was initiated later for VRE than for ARE bacteremia, this did not appear to

50 mediate the increased mortality risk.

51 Conclusions Compared to ARE bacteremia, VRE bacteremia was associated with higher 30-day

52 mortality. One explanation for this association would be increased virulence of VRE, although

53 both phenotypes belong to the same well-characterized core genomic lineage. Alternatively, it

54 may be the result of unmeasured confounding. 
medRxiv preprint doi: https://doi.org/10.1101/2020.05.10.20049783; this version posted May 15, 2020. The copyright holder for this preprint (which was not certified by peer review) is the author/funder, who has granted medRxiv a license to display the preprint in perpetuity.

It is made available under a CC-BY-NC 4.0 International license .

\section{Introduction}

56 As many other countries, the Netherlands and Denmark have faced increasingly frequent

57 polyclonal hospital outbreaks of Enterococcus faecium with combined resistance to ampicillin

58 and vancomycin (VRE) during the past years [1,2]. In these countries, ampicillin-resistant,

59 vancomycin-susceptible $E$. faecium (ARE) has become the dominant hospital phenotype of $E$.

60 faecium in recent decades [2,3]. Since hospital-acquired VRE and ARE are genetically

61 indistinguishable at the core genome level, VRE is assumed to have originated from the

62 omnipresent ARE through acquisition of vanA or vanB genes [4-7]. In both countries, infection

63 control policies have been implemented to prevent nosocomial transmission of VRE (contact

64 precautions for VRE carriers, supplemented by contact tracing and augmented general hygiene

65 measures in case of outbreaks $[8,9])$, but not for ARE. Failure to control VRE transmission will

66 most likely result in VRE endemicity, because the nosocomial ARE populations will in part be

67 supplanted by VRE $[3,10]$.

68 Controlling VRE outbreaks imposes a great burden on finances and hospital personnel [11]. To

69 make an appropriate cost-benefit analysis of containing VRE spread in a healthcare system, it is

70 essential to quantify the benefits of such a strategy. The most important threat for individual

71 patients is the adversity patients will experience due to VRE infection as compared to ARE

72 infection. A meta-analysis reported increased mortality after VRE bacteremia compared to ARE

73 bacteremia [12], but most studies included had been performed before effective antibiotics for

74 VRE were available. Since then, few have attempted to quantify the effects of VRE infection

75 compared to ARE infection, and those available often suffered from methodological drawbacks, 
medRxiv preprint doi: https://doi.org/10.1101/2020.05.10.20049783; this version posted May 15, 2020. The copyright holder for this preprint (which was not certified by peer review) is the author/funder, who has granted medRxiv a license to display the preprint in perpetuity.

It is made available under a CC-BY-NC 4.0 International license .

76 such as combining E. faecium and Enterococcus faecalis infection and incomplete control for

77 confounding [13].

78 We, therefore, sought to investigate the fraction of mortality in VRE bacteremia superimposed

79 by vancomycin resistance, in both the Netherlands and Denmark. We also analyzed whether any

80 such increase is the result of a delay in appropriate antibiotic therapy, as this is a priori the most

81 likely mediating mechanism.

\section{Methods}

83 Study design, setting and participants

84 We addressed a causal research question with an observational study in which confounding bias

85 was dealt with in a two-stepped approach. First, by means of matching, patients with ARE

86 bacteremia and with underlying disease severity similar to the VRE bacteremia patients were

87 chosen as comparison group. Second, we controlled for remaining imbalances in confounding

88 factors after matching by means of adjustment in multivariable models.

89 This resulted in a retrospective matched cohort study in which episodes of bacteremia caused by

90 E. faecium with co-resistance to ampicillin and vancomycin (designated as VRE) were compared

91 to control episodes of bacteremia caused by E. faecium with resistance to ampicillin and

92 susceptibility to vancomycin (designated as ARE). Episodes with ampicillin-susceptible VRE

93 bacteremias were excluded. Depending on the availability, a maximum of 4 ARE bacteremias

94 were matched to each VRE bacteremia, using the variables hospital, hospital ward at bacteremia 
medRxiv preprint doi: https://doi.org/10.1101/2020.05.10.20049783; this version posted May 15, 2020. The copyright holder for this preprint (which was not certified by peer review) is the author/funder, who has granted medRxiv a license to display the preprint in perpetuity.

It is made available under a CC-BY-NC 4.0 International license .

95 onset, age and length of stay prior to bacteremia (see Supplementary Material for a complete

96 description).

97 No formal sample size calculation was performed, as in both involved countries, VRE

98 bacteremias are rare occurrences, and we had to rely on the willingness of hospitals country-

99 wide to participate. In the Netherlands, VRE bacteremia episodes were identified in 13 hospitals

100 through the national surveillance system ISIS-AR [14], and eleven participated in this study, as

101 did five hospitals not linked to ISIS-AR (see Supplementary Table 1 for details of participating

102 hospitals). In Denmark, the DACOBAN database was used to identify patients with VRE

103 bacteremia. DACOBAN is a registry of all positive blood cultures from 10 of 11 hospitals in the

104 Capital Region of Denmark (the exception being the tertiary referral center Rigshospitalet) [15].

105 Patients with VRE bacteremia were identified in five hospitals of which four participated in this

106 study.

107 In the Netherlands, we included patients with VRE bacteremia that occurred between 1 January

1082009 and 1 January 2013, with deviations in some hospitals (Supplementary Table 1). In

109 Denmark, we included patients with VRE bacteremia that occurred between 1 January 2012 and

1101 January 2015.

111 Minimum inhibitory concentrations (MICs) for ampicillin and vancomycin were used as reported

112 by local laboratories. All Danish laboratories interpreted antimicrobial susceptibility according to

113 EUCAST standards, but most Dutch laboratories switched from CLSI to EUCAST standards in

114 recent years [14]. Vancomycin resistance had to be confirmed by E-test or demonstration of the

115 presence of vanA or vanB. The specific VRE genotype was based on PCR-testing or on 
medRxiv preprint doi: https://doi.org/10.1101/2020.05.10.20049783; this version posted May 15, 2020. The copyright holder for this preprint (which was not certified by peer review) is the author/funder, who has granted medRxiv a license to display the preprint in perpetuity. It is made available under a CC-BY-NC 4.0 International license .

116 teicoplanin susceptibility (resistant categorized as vanA, susceptible as vanB) if PCR testing had

117 not been performed.

118 The Institutional Review Board of the coordinating center judged the study to be exempt from

119 the Dutch Medical Research Involving Human Subjects Law due to its retrospective nature.

120 Informed consent was not necessary, as data were provided anonymized by treating physicians.

121 In all participating study sites, local regulations for such studies were followed. In Denmark, the

122 study was approved by the Danish Data Protection Agency (registered under 2012-58-0004) and

123 the Danish Health and Medicines Authority (registered under 3-3013-1118/1).

\section{Data collection}

125 After selection of cases and controls, charts were manually reviewed with the date of the index

126 blood culture (bacteremia onset) as reference date. A description of the potential confounding

127 variables and infection-related variables for which data were collected is provided in the

128 Supplementary Material.

129 Additionally, antibiotic use was registered from 30 days prior to bacteremia onset until 14 days

130 after onset, including type of antibiotic, route of administration, and starting and stopping dates.

131 Antibiotic use prior to bacteremia was considered a potential confounder, whereas treatment

132 provided for the $E$. faecium bacteremia episode was considered the main intermediate variable

133 on the causal pathway leading from vancomycin resistance to increased mortality. To analyze

134 this variable, on each calendar day from bacteremia onset onwards (considered day 0 ), antibiotic

135 treatment was categorized as (a) either E. faecium-covering (i.e. including vancomycin, linezolid,

136 daptomycin, teicoplanin, quinupristin/dalfopristin and/or tigecyclin, regardless of vancomycin 
medRxiv preprint doi: https://doi.org/10.1101/2020.05.10.20049783; this version posted May 15, 2020. The copyright holder for this preprint (which was not certified by peer review) is the author/funder, who has granted medRxiv a license to display the preprint in perpetuity.

It is made available under a CC-BY-NC 4.0 International license .

137 resistance phenotype) or not, and (b) appropriate (i.e. all of the aforementioned antibiotics for

138 ARE infection, all except vancomycin for vanB VRE infection, and all except vancomycin and 139 teicoplanin for vanA VRE infection) or inappropriate.

140 The primary outcome of the study was mortality within 30 days of bacteremia onset, and

141 secondary outcomes were mortality within 1 year, in-hospital mortality, length of hospital stay

142 after bacteremia onset, and intensive care unit admission within 7 days of bacteremia onset. For

143 all bacteremia cases, follow-up data (censoring date or date of death) for at least 30 days after

144 bacteremia onset, but preferably up to 1 year after bacteremia onset were collected.

145 Statistical analysis

146 The relation between ARE/VRE and 30-day mortality was estimated using Cox regression

147 models, unadjusted as well as adjusted for potential confounding variables. All models were Cox

148 proportional hazards models, with stratification on matched sets, robust standard errors, and

149 correlation between individuals that were included multiple times. For models without

150 censoring, all episodes were given the same arbitrary follow-up time and the Efron

151 approximation for tied survival times was used, so that hazard ratios (HR) could be interpreted

152 as risk ratios (RR) [16]. The standard adjusted models involved inclusion of all potential

153 confounders a priori deemed relevant by us to achieve optimal correction, followed by removal

154 of redundant variables to increase precision [17]. As a sensitivity analysis, stepwise addition and

155 removal of potential confounders was performed, starting from a model including only the

156 exposure of interest. In the Supplementary Material, exact procedures are described. In case of

157 missing values for the variables included in a model, individuals were excluded from the analysis. 
medRxiv preprint doi: https://doi.org/10.1101/2020.05.10.20049783; this version posted May 15, 2020. The copyright holder for this preprint (which was not certified by peer review) is the author/funder, who has granted medRxiv a license to display the preprint in perpetuity.

It is made available under a CC-BY-NC 4.0 International license.

158 Several additional models were created to evaluate mediation of the effect of VRE on mortality

159 through appropriateness of therapy. For this, an interaction between vancomycin resistance and

160 appropriateness of therapy was included. As appropriateness of therapy is a time-varying

161 variable, three models were created in which the baseline was moved to the end of day 0 (day of

162 the index blood culture), +1 , and +2 , respectively. Patients having died or censored before or on

163 the day of the baseline were removed from the analysis. Appropriateness of therapy in each

164 model reflected the state at baseline.

165 All statistical analyses were performed in R (version 3.6.1) [18], with the use of packages survival

166 [19], cmprsk [20], rms [21], mice [22] and xtable [23].

167 Results

Patient characteristics

169 In all, 63 VRE episodes were matched to 234 ARE episodes (36 and 130 for the Netherlands, and

17027 and 104 for Denmark). VRE and matched ARE bacteremia episodes had largely similar

171 characteristics (Table 1 and Supplementary Table 2). Differences between both countries were

172 also present, most prominently involving treatment restriction prior to bacteremia. The latter

173 variable is generally registered on a dedicated location in Dutch health records, but had to be

174 abstracted from written notes in Denmark. Also, comorbidities were retrieved from the

175 DACOBAN registry in Denmark, whereas they were abstracted from medical notes in the

176 Netherlands. 
medRxiv preprint doi: https://doi.org/10.1101/2020.05.10.20049783; this version posted May 15, 2020. The copyright holder for this preprint (which was not certified by peer review) is the author/funder, who has granted medRxiv a license to display the preprint in perpetuity.

It is made available under a CC-BY-NC 4.0 International license .

177 Most VRE were vanA $(n=41,65 \%), 19$ were vanB $(30 \%)$, one isolate carried both vanA and vanB

178 and two isolates could not be categorized. All VRE isolates from Denmark $(n=27)$ were vanA.

179 Seventeen isolates were categorized based on teicoplanin susceptibility ( 3 vanA and 14 vanB, all

180 from the Netherlands).

181 Mortality

182 All patients could be assessed for 30 -day mortality, and $76 \%$ of censored patients had a follow-

183 up time of at least one year. Crude 30 -day mortality was $40 \%$ for VRE and $32 \%$ for ARE: $33 \%$ and

$18427 \%$ for VRE and ARE, respectively, in the Netherlands and $48 \%$ and $38 \%$ in Denmark. In the

185 Netherlands, 30-day mortality per VRE phenotype was $29 \%$ for vanA and $37 \%$ for vanB. The

186 unadjusted RR for 30-day mortality of VRE (compared to ARE) was 1.27 (95\% confidence interval

187 (CI) $0.87-1.84 ; 1.16$ (95\% CI 0.65-2.06) for the Netherlands, 1.37 (95\% CI 0.84-2.25) for Denmark;

188 Table 2). Adjustment for confounding increased the RR to 1.54 (95\% CI 1.06-2.25). Within the

189 Dutch subgroup, addition of the confounder Acute Physiology Score before bacteremia onset to

190 an otherwise optimally adjusted model reduced the RR of vancomycin resistance from 1.62 to

1911.17 (see Supplementary Material).

192 One year mortality was larger among Danish patients with VRE compared to patients with ARE

193 bacteremia or Dutch patients with VRE or ARE bacteremia (Figure 1). In the multivariable Cox

194 model for mortality up to one year, the HR for VRE amounted to 1.25 (95\% CI $0.80-1.98$; Table

$1953)$. 
medRxiv preprint doi: https://doi.org/10.1101/2020.05.10.20049783; this version posted May 15, 2020. The copyright holder for this preprint (which was not certified by peer review) is the author/funder, who has granted medRxiv a license to display the preprint in perpetuity.

It is made available under a CC-BY-NC 4.0 International license .

Antibiotic therapy

197 Visual inspection of cumulative incidence plots revealed that initiation of $E$. faecium-covering

198 antibiotic therapy occurred faster in VRE than in ARE episodes (Figure 2), but that initiation of

199 appropriate antibiotic therapy occurred faster for ARE compared to VRE bacteremia (Figure 3). In

200 Denmark, appropriate antibiotic therapy for both ARE and VRE bacteremia was started earlier

201 than in the Netherlands, and often consisted of linezolid daptomycin combination treatment

202 (Table 4).

203 Inclusion of inappropriate antibiotic therapy on the day of the index blood culture (day 0 ), in

204 itself associated with mortality (RR 2.79 (95\% CI 0.99-7.86)), did not alter the effect of VRE on 30

205 day mortality (Table 2). In models with an interaction between vancomycin resistance and

206 appropriateness of therapy, VRE patients on inappropriate therapy increasingly fared worse over

207 time compared to ARE patients on inappropriate therapy (Table 5). ARE patients on appropriate

208 therapy had better survival than those on inappropriate therapy, but this protective effect

209 seemed to diminish over time. The effect estimates for VRE patients on appropriate therapy

210 were uncertain.

\section{Discussion}

212 This study reveals that, after matching and further analytic control for confounders, VRE

213 bacteremia was, compared to ARE bacteremia, associated with 54\% higher risk for mortality after

21430 days (RR 1.54, 95\% CI 1.06-2.25). Yet, this increased risk of death must be explained by other

215 factors than a delay in appropriate antibiotic therapy. 
medRxiv preprint doi: https://doi.org/10.1101/2020.05.10.20049783; this version posted May 15, 2020. The copyright holder for this preprint (which was not certified by peer review) is the author/funder, who has granted medRxiv a license to display the preprint in perpetuity. It is made available under a CC-BY-NC 4.0 International license .

216 Our estimate for the effect of VRE on mortality is similar to the reported pooled OR of 2.52 (95\%

217 CI 1.9-3.4) in a meta-analysis from 2005 [12], which translates to a RR of 1.70 in case of $32 \%$

218 death rate in the non-exposed group [24]. This seems remarkably identical, as the studies

219 included in that meta-analysis had been performed before the availability of effective antibiotics

220 for VRE, such as linezolid and daptomycin. Yet, a small study comparing older and newer

221 antibiotics in 113 VRE bacteremias concluded that newer antibiotics had not brought

222 discernable benefits to patient outcome [25]. A later meta-analysis on the effect of VRE on

223 mortality in the era of effective antibiotic therapy could only present an unadjusted estimate,

224 and hence cannot be compared to our study [13]. Recent Australian and German studies all

225 found point estimates reflecting increased mortality in case of vancomycin resistance, with

226 confidence intervals indicating non-significance [26-28]. By analyzing the $E$. faecium bacteremia

227 subset and not including intermediate variables in the adjusted model, the OR of $1.283(95 \% \mathrm{CI}$

228 0.801-2.057) from Kramer et al. most closely reflects our estimation procedure [27].

229 There are three causal pathways along which vancomycin resistance could lead to increased

230 mortality: (i) increased virulence of VRE compared to ARE, (ii) less effective antibiotics for VRE

231 than for ARE, and (iii) a delay in initiation of appropriate antibiotic therapy for VRE bacteremia.

232 We cannot fully exclude a systematic difference in pathogenicity between ARE and VRE, as for

233 example Bender et al. have shown that acquisition of vanB by E. faecium is accompanied by the

234 transfer of larger genetic fragments [29]. However, most studies conclude that both phenotypes

235 belong to the same, well-characterized, core genomic lineage of $E$. faecium $[4,7]$. Furthermore, to

236 the best of our knowledge, there is no evidence that the appropriate antibiotic options for $E$.

237 faecium, most prominently vancomycin, linezolid or daptomycin, have different efficacy for 
medRxiv preprint doi: https://doi.org/10.1101/2020.05.10.20049783; this version posted May 15, 2020. The copyright holder for this preprint (which was not certified by peer review) is the author/funder, who has granted medRxiv a license to display the preprint in perpetuity.

It is made available under a CC-BY-NC 4.0 International license .

238 susceptible strains. In this study, vancomycin was mostly used for ARE, and linezolid and

239 daptomycin for VRE.

240 The observed increased mortality in case of VRE bacteremia, therefore, could be expected to

241 result from a delay in appropriate therapy, which has been implicated previously in worse

242 outcomes in case of enterococcal bacteremia [30]. However, our models that include

243 appropriateness of therapy do not offer support for this hypothesis. VRE patients on

244 inappropriate therapy continuously fare worse than ARE patients on inappropriate therapy.

245 Therapy over time may be reflective of the evolving disease severity of the patient, and collider

246 bias may be induced by conditioning on appropriateness of therapy [31]. This means that effect

247 estimates of appropriateness of therapy after baseline may not reflect true causal associations.

248 However, seeing that this trend is discernable from the day of the index blood culture onwards

249 increases our confidence that the difference in duration until appropriate therapy is unable to

250 explain the increased mortality in case of VRE bacteremia. A final indication for this stems from

251 the comparison between countries in this study. Overall mortality in Denmark for both ARE and

252 VRE bacteremia is higher than in Netherlands, although appropriate therapy for both types of

253 bacteremia is initiated considerably faster in Denmark than in the Netherlands.

254 As these biologically plausible mediators cannot explain increased mortality due to vancomycin

255 resistance, the possibility remains that these observed effects are due to unmeasured

256 confounding. This possibility is supported by two additional observations. First, a measure for

257 clinical disease severity immediately before bacteremia onset was not available for the Danish

258 patients. For the Dutch patients, we could calculate the Acute Physiology score, and when 
medRxiv preprint doi: https://doi.org/10.1101/2020.05.10.20049783; this version posted May 15, 2020. The copyright holder for this preprint (which was not certified by peer review) is the author/funder, who has granted medRxiv a license to display the preprint in perpetuity. It is made available under a CC-BY-NC 4.0 International license .

259 included in our country-specific analyses, it substantially reduced the effect estimate for

260 mortality (see Supplementary Material). Second, the association between vancomycin resistance

261 and mortality persisted over the course of a full year. Infections may have long-term sequelae

262 [32], but it seems unlikely that sustained mortality differences will emerge that can be causally

263 related to vancomycin resistance. A Dutch population-based study reported that the incidence

264 of recurrent bacteremia, an example of a long-term consequence, only marginally differed

265 between ARE and VRE bacteremia [33]. An alternative explanation is that underlying prognostic

266 factors at the time of onset of enterococcal bacteremia were dissimilar.

267 Several limitations of this study should be discussed. First, results of this study may not apply to

268 E. faecium bacteremia in general, as a non-random subset of ARE bacteremias was included. The

269 matched design does not allow for direct comparisons of raw proportions other than for VRE vs.

270 ARE. Second, some loss in precision may be expected in stratified analyses, as not all matched

271 sets can be used for parameter estimation. Third, measurements of comorbidities and treatment

272 restrictions differed between both countries, whereas these differences were not included in

273 models. Fourth, duration until initiation of appropriate therapy could not be reliably measured in

274 hours, and was reflected instead by calendar days.

275 Finally, some studies suggest that the incidence of infections with VRE occur on top of the

276 existing incidence of infections caused by vancomycin-susceptible enterococci $[34,35]$. In that

277 case, a comparison between VRE bacteremia and an uninfected control group would be more

278 appropriate, as described by Chiang et al. [36]. Yet, it is important to note that these incidence

279 rates may have been confounded by the fact that $E$. faecalis was not separated from $E$. faecium, 
medRxiv preprint doi: https://doi.org/10.1101/2020.05.10.20049783; this version posted May 15, 2020. The copyright holder for this preprint (which was not certified by peer review) is the author/funder, who has granted medRxiv a license to display the preprint in perpetuity.

It is made available under a CC-BY-NC 4.0 International license .

280 and that results from molecular epidemiological studies provided strong evidence that ARE and

281 VRE occupy the same niche within the bacterial hospital ecology [4].

282 In conclusion, VRE bacteremia was, when compared to ARE bacteremia, associated with higher

283 mortality. This could not be explained by delays in initiation of appropriate antibiotic therapy,

284 although the relevant models are possibly underpowered and should be interpreted with

285 caution. Because of the large heterogeneity among infected patients and the multiple

286 determinants that mediate the outcome for patients developing $E$. faecium bacteremia,

287 unmeasured confounding is a likely explanation. In that case, replacement of ARE infections by

288 VRE infections would not lead to higher 30-day mortality. The alternative explanation is that VRE

289 is more virulent than ARE. Given the resemblance of the core genomes of ARE and VRE, the

290 genetic basis for hypervirulence would then be most likely encoded in the accessory genome,

291 the mobilome. In that case, emergence of VRE could not only replace ARE infections but also

292 increase the total burden of infection. Further studies are warranted to explore this possibility. 
medRxiv preprint doi: https://doi.org/10.1101/2020.05.10.20049783; this version posted May 15, 2020. The copyright holder for this preprint (which was not certified by peer review) is the author/funder, who has granted medRxiv a license to display the preprint in perpetuity.

It is made available under a CC-BY-NC 4.0 International license .

\section{Funding}

294 This work was supported by a research grant from the Netherlands Organisation for Health

295 Research and Development [grant number 205200007] to W.C.R.

\section{Acknowledgment}

298 We would like to thank all participating hospitals for making data collection possible. We

299 specifically thank Marja Smid for her assistance with the data collection in the Netherlands, and

300 Kim Gradel and Steen Rasmussen for extraction of comorbidity data in Denmark. We also thank

301 Rob Willems for critically reviewing an earlier version of this manuscript.

302 The Dutch VRE Bacteremia Investigators study group consists of: Heidi S.M. Ammerlaan (Catharina

303 Ziekenhuis, Eindhoven), Akke K. van der Bij (National Institute for Public Health and the

304 Environment (RIVM), Bilthoven; present affiliation: Diakonessenhuis, Utrecht), Sybrandus N. Blank

305 (Maxima Medisch Centrum, Eindhoven/Veldhoven), Marc J.M. Bonten (Universitair Medisch

306 Centrum, Utrecht), Els I.G.B. de Brauwer (Zuyderland, Heerlen/Sittard-Geleen), Mirjam J.D.

307 Dautzenberg (Universitair Medisch Centrum, Utrecht; present affiliation: Radboudumc,

308 Nijmegen), Laura van Dommelen (Stichting PAMM, Veldhoven), Paul Gruteke (Onze Lieve

309 Vrouwe Gasthuis, Amsterdam; Flevoziekenhuis, Almere), Rogier Jansen (Onze Lieve Vrouwe

310 Gasthuis, Amsterdam), Saskia Kuipers (Radboudumc, Nijmegen), Marrigje H. Nabuurs-Franssen

311 (Canisius-Wilhelmina Ziekenhuis, Nijmegen), Lieke Möller (Certe, Groningen), Jacobus M.

312 Ossewaarde (Maasstad Ziekenhuis, Rotterdam), Wouter C. Rottier (Universitair Medisch Centrum, 
medRxiv preprint doi: https://doi.org/10.1101/2020.05.10.20049783; this version posted May 15, 2020. The copyright holder for this preprint (which was not certified by peer review) is the author/funder, who has granted medRxiv a license to display the preprint in perpetuity. It is made available under a CC-BY-NC 4.0 International license .

313 Utrecht), Wouter Rozemeijer (Noordwest Ziekenhuisgroep, Alkmaar), Gijs J.H.M. Ruijs (Isala,

314 Zwolle), Annelot F. Schoffelen (National Institute for Public Health and the Environment (RIVM),

315 Bilthoven), Fre W. Sebens (Deventer Ziekenhuis, Deventer; present affiliation: LabMicTA,

316 Hengelo), Peter M. Schneeberger (Jeroen Bosch Ziekenhuis, 's-Hertogenbosch), Matthijs

317 Tersmette (St. Antonius Ziekenhuis, Utrecht/Nieuwegein), Saara J. Vainio (VU medisch centrum,

318 Amsterdam; present affiliation: St. Antonius Ziekenhuis, Utrecht/Nieuwegein), G. Paul Voorn (St.

319 Antonius Ziekenhuis, Utrecht/Nieuwegein)

320 The Danish Collaborative Bacteraemia Network (DACOBAN) study group consists of: Magnus Arpi,

321 Kim O. Gradel, Ulrich S. Jensen, Jenny D. Knudsen, Kristoffer Koch, Henrik C. Schønheyder, Mette

322 Søgaard, Sara Thønnings, Jesper Smit, Mette Pinholt, Christian $\varnothing$. Andersen

323 Results from this study were presented at the 25th European Congress of Clinical Microbiology

324 and Infectious Diseases, Copenhagen, Denmark (25-28 April 2015, oral presentation O090).

325 Potential conflicts of interest. All authors: No conflict. 
medRxiv preprint doi: https://doi.org/10.1101/2020.05.10.20049783; this version posted May 15, 2020. The copyright holder for this preprint (which was not certified by peer review) is the author/funder, who has granted medRxiv a license to display the preprint in perpetuity.

It is made available under a CC-BY-NC 4.0 International license .

\section{References}

327 1. de Greeff SC, Mouton JW. NethMap 2017: consumption of antimicrobial agents and antimicrobial resistance among medically important bacteria in the Netherlands in 2016. Bergen, the Netherlands: Stichting Werkgroep Antibioticabeleid \& Rijksinstituut voor Volksgezondheid en Milieu, 2017.

331 2. Borck Høg B, Korsgaard H, Sönksen UW. DANMAP 2016: use of antimicrobial agents and occurrence of antimicrobial resistance in bacteria from food animals, food and humans in Denmark. Lyngby \& Copenhagen, Denmark: Statens Serum Institut, DTU Veterinærinstituttet \& DTU Fødevareinstituttet, 2017.

3. Top J, Willems RJL, Bonten MJM. Emergence of CC17 Enterococcus faecium: from commensal to hospital-adapted pathogen. FEMS Immunol Med Microbiol 2008; 52:297308.

4. Guzman Prieto AM, van Schaik W, Rogers MRC, et al. Global emergence and dissemination of enterococci as nosocomial pathogens: Attack of the clones? Front Microbiol 2016; 7:788.

341 5. Howden BP, Holt KE, Lam MMC, et al. Genomic insights to control the emergence of vancomycin-resistant enterococci. MBio 2013; 4:e00412-13.

343 6. Pinholt M, Gumpert H, Bayliss S, et al. Genomic analysis of 495 vancomycin-resistant 344 Enterococcus faecium reveals broad dissemination of a vanA plasmid in more than 19 345 clones from Copenhagen, Denmark. J Antimicrob Chemother 2017; 72:40-47. 
medRxiv preprint doi: https://doi.org/10.1101/2020.05.10.20049783; this version posted May 15, 2020. The copyright holder for this preprint (which was not certified by peer review) is the author/funder, who has granted medRxiv a license to display the preprint in perpetuity. It is made available under a CC-BY-NC 4.0 International license .

346 7. Raven KE, Reuter S, Reynolds R, et al. A decade of genomic history for healthcare347 associated Enterococcus faecium in the United Kingdom and Ireland. Genome Res 2016; $348 \quad 26: 1388-1396$.

349 8. Bijzonder resistente micro-organismen (BRMO). Leiden, the Netherlands: Werkgroep $350 \quad$ Infectiepreventie, 2013.

351 9. Nationale infektionshygiejniske retningslinjer om supplerende forholdsregler ved infektioner og bærertilstand i sundhedssektoren (5. udgave). Copenhagen, Denmark:

353 Central Enhed for Infektionhygiejne (Statens Serum Institut), 2016.

354 10. Johnstone J, Policarpio ME, Lam F, et al. Rates of blood cultures positive for vancomycin355 356 resistant Enterococcus in Ontario: a quasi-experimental study. CMAJ Open 2017; 5:E273E280.

12. DiazGranados CA, Zimmer SM, Klein M, Jernigan JA. Comparison of mortality associated with vancomycin-resistant and vancomycin-susceptible enterococcal bloodstream infections: a meta-analysis. Clin Infect Dis 2005; 41:327-33. the era of effective VRE therapy: a systematic review and meta-analysis. Infect Control Hosp Epidemiol 2016; 37:26-35. 
medRxiv preprint doi: https://doi.org/10.1101/2020.05.10.20049783; this version posted May 15, 2020. The copyright holder for this preprint (which was not certified by peer review) is the author/funder, who has granted medRxiv a license to display the preprint in perpetuity. It is made available under a CC-BY-NC 4.0 International license.

surveillance system for antimicrobial resistance: a successful tool to support the control of antimicrobial resistance in the Netherlands. Euro Surveill 2017; 22:pii=17-00062.

15. Gradel KO, Schønheyder HC, Arpi M, Knudsen JD, Østergaard C, Søgaard M. The Danish Collaborative Bacteraemia Network (DACOBAN) database. Clin Epidemiol 2014; 6:301308.

371 16. Cummings P. Re: 'Estimating the relative risk in cohort studies and clinical trials of common outcomes'. Am J Epidemiol 2004; 159:213.

373 17. Greenland S, Daniel R, Pearce N. Outcome modelling strategies in epidemiology: traditional methods and basic alternatives. Int J Epidemiol 2016; 45:565-575.

375 18. R Core Team. R: A language and environment for statistical computing. Vienna, Austria: 2020.

377 19. Therneau T. A package for survival analysis in R ( $\mathrm{R}$ package version 3.1-11). 2020;

378 20. Gray B. cmprsk: subdistribution analysis of competing risks (R package version 2.2-9).

$379 \quad 2019$;

380 21. Harrell Jr FE. rms: Regression Modeling Strategies (R package version 5.1-4). 2019;

381 22. Buuren S van, Groothuis-Oudshoorn K. mice: multivariate imputation by chained 382 equations in R. J Stat Softw 2011; 45.

383 23. Dahl DB, Scott D, Roosen C, Magnusson A, Swinton J. xtable: export tables to LaTeX or $384 \quad$ HTML (R package version 1.8-4). 2019; 
medRxiv preprint doi: https://doi.org/10.1101/2020.05.10.20049783; this version posted May 15, 2020. The copyright holder for this preprint (which was not certified by peer review) is the author/funder, who has granted medRxiv a license to display the preprint in perpetuity. It is made available under a CC-BY-NC 4.0 International license .

385 24. Zhang J, Yu KF. What's the relative risk? A method of correcting the odds ratio in cohort studies of common outcomes. JAMA 1998; 280:1690-1.

387 25. Erlandson KM, Sun J, Iwen PC, Rupp ME. Impact of the more-potent antibiotics quinupristin-dalfopristin and linezolid on outcome measure of patients with vancomycinresistant Enterococcus bacteremia. Clin Infect Dis 2008; 46:30-6.

26. Cheah ALY, Spelman T, Liew D, et al. Enterococcal bacteraemia: factors influencing mortality, length of stay and costs of hospitalization. Clin Microbiol Infect 2013; 19:E181E189.

27. Kramer TS, Remschmidt C, Werner S, et al. The importance of adjusting for enterococcus

2018; 7:133.

28. Dubler $\mathrm{S}$, Lenz M, Zimmermann $\mathrm{S}$, et al. Does vancomycin resistance increase mortality in Enterococcus faecium bacteraemia after orthotopic liver transplantation? A retrospective study. Antimicrob Resist Infect Control 2020; 9:22.

400 29. Bender JK, Kalmbach A, Fleige C, Klare I, Fuchs S, Werner G. Population structure and acquisition of the vanB resistance determinant in German clinical isolates of Enterococcus faecium ST192. Sci Rep 2016; 6:21847.

403 30. Zasowski EJ, Claeys KC, Lagnf AM, Davis SL, Rybak MJ. Time is of the essence: the impact of delayed antibiotic therapy on patient outcomes in hospital-onset enterococcal 
medRxiv preprint doi: https://doi.org/10.1101/2020.05.10.20049783; this version posted May 15, 2020. The copyright holder for this preprint (which was not certified by peer review) is the author/funder, who has granted medRxiv a license to display the preprint in perpetuity.

It is made available under a CC-BY-NC 4.0 International license.

bloodstream infections. Clin Infect Dis 2016; 62:1242-1250.

406 31. Hernán MA, Hernández-Díaz S, Robins JM. A structural approach to selection bias. Epidemiology 2004; 15:615-25.

408 32. Leibovici L. Long-term consequences of severe infections. Clin Microbiol Infect 2013;

409 19:510-512.

33. Woudt SHS, de Greeff SC, Schoffelen AF, Vlek ALM, Bonten MJM, Infectious Diseases Surveillance Information System-Antimicrobial Resistance (ISIS-AR) Study Group. Antibiotic resistance and the risk of recurrent bacteremia. Clin Infect Dis 2018; 66:16511657.

414 34. Ammerlaan HSM, Harbarth S, Buiting AGM, et al. Secular trends in nosocomial bloodstream infections: antibiotic-resistant bacteria increase the total burden of infection. Clin Infect Dis 2013; 56:798-805.

417 35. Popiel KY, Miller MA. Evaluation of vancomycin-resistant enterococci (VRE)-associated morbidity following relaxation of VRE screening and isolation precautions in a tertiary care hospital. Infect Control Hosp Epidemiol 2014; 35:818-25.

420 36. Chiang $\mathrm{H}-\mathrm{Y}$, Perencevich EN, Nair R, et al. Incidence and outcomes associated with 421 infections caused by vancomycin-resistant enterococci in the United States: systematic $422 \quad$ literature review and meta-analysis. Infect Control Hosp Epidemiol 2017; 38:203-215. 
Table 1. Characteristics and outcomes of VRE and matched ARE bacteremias

\begin{tabular}{|c|c|c|c|c|}
\hline & \multicolumn{2}{|c|}{ Netherlands } & \multicolumn{2}{|c|}{ Denmark } \\
\hline & $\begin{array}{l}\text { ARE bacteremia, } \\
\text { n/N with data } \\
\text { (\%) }\end{array}$ & \begin{tabular}{|c|} 
VRE bacteremia, \\
n/N with data \\
(\%)
\end{tabular} & \begin{tabular}{|c|} 
ARE bacteremia, \\
n/N with data \\
(\%)
\end{tabular} & \begin{tabular}{|c|} 
VRE bacteremia, \\
n/N with data \\
(\%)
\end{tabular} \\
\hline \multicolumn{5}{|l|}{ Potential confounding variables } \\
\hline Female & $47 / 130(36)$ & $19 / 36(53)$ & $51 / 104(49)$ & $10 / 27(37)$ \\
\hline \multicolumn{5}{|l|}{ Hospital ward at bacteremia onset } \\
\hline - Internal medicine & $47 / 130(36)$ & $15 / 36(42)$ & $31 / 104(30)$ & $8 / 27(30)$ \\
\hline$-\mathrm{ICU}$ & $48 / 130(37)$ & $11 / 36(31)$ & $25 / 104(24)$ & $6 / 27(22)$ \\
\hline - Gastro-enterology/surgery & $34 / 130(26)$ & $9 / 36(25)$ & $31 / 104(30)$ & $8 / 27(30)$ \\
\hline - Other & $1 / 130(1)$ & $1 / 36(3)$ & $17 / 104(16)$ & $5 / 27(19)$ \\
\hline \multicolumn{5}{|l|}{ Bacteremia origin } \\
\hline - Community-onset & $2 / 130(2)$ & $3 / 36(8)$ & $1 / 104(1)$ & $1 / 27(4)$ \\
\hline Length of hospital stay prior to bacteremia, median (IQR) & $17(11-24)$ & $20(14-36)$ & $18(6-24)$ & $21(10-29)$ \\
\hline $\begin{array}{l}\text { Preceding hospital admission within } 3 \text { months prior to } \\
\text { bacteremia }\end{array}$ & $58 / 130(45)$ & $15 / 36(42)$ & $47 / 103(46)$ & $13 / 26(50)$ \\
\hline Charlson index, median (IQR) & $2(2-3)$ & $2(1-4)$ & $3(1-4)$ & $3(2-6)$ \\
\hline Hematological malignancy - under treatment & $31 / 130(24)$ & $10 / 36(28)$ & 9/104 (9) & $6 / 27(22)$ \\
\hline Metastasized solid malignancy & $13 / 130(10)$ & $1 / 36(3)$ & $13 / 104(12)$ & $6 / 27(22)$ \\
\hline Neutropenia at bacteremia onset & $32 / 130(25)$ & $11 / 36(31)$ & $8 / 104(8)$ & $6 / 27(22)$ \\
\hline
\end{tabular}




\begin{tabular}{|c|c|c|c|c|}
\hline Treatment restriction in place at bacteremia onset & $26 / 130(20)$ & $10 / 36(28)$ & $5 / 102(5)$ & $2 / 27(7)$ \\
\hline \multicolumn{5}{|l|}{ Known colonization with $E$. faecium } \\
\hline - Yes: ARE & $38 / 130(29)$ & $7 / 36(19)$ & $16 / 104(15)$ & $2 / 27(7)$ \\
\hline - Yes: VRE & $2 / 130(2)$ & $11 / 36(31)$ & $0 / 104(0)$ & $9 / 27(33)$ \\
\hline Vancomycin use within 30 days prior to bacteremia & $13 / 130(10)$ & $15 / 36(42)$ & 9/104 (9) & $6 / 27(22)$ \\
\hline \multicolumn{5}{|l|}{ Infection-related variables } \\
\hline Polymicrobial bacteremia & $35 / 130(27)$ & $8 / 36(22)$ & $31 / 103(30)$ & $11 / 27(41)$ \\
\hline Severe sepsis at bacteremia onset & $30 / 129(23)$ & $10 / 36(28)$ & $20 / 104(19)$ & $4 / 27(15)$ \\
\hline - Biliary tract infection & $15 / 130(12)$ & $4 / 36(11)$ & $10 / 104(10)$ & $2 / 27(7)$ \\
\hline - Other intra-abdominal infection & $35 / 130(27)$ & $9 / 36(25)$ & $12 / 104(12)$ & $7 / 27(26)$ \\
\hline - Other & 20/130 (15) & $4 / 36(11)$ & $23 / 104(22)$ & $7 / 27(26)$ \\
\hline $\begin{array}{l}\text { Source control performed before day }+7^{a} \text { (if applicable to } \\
\text { source) }\end{array}$ & $38 / 79(48)$ & $8 / 19(42)$ & $25 / 47(53)$ & 4/13 (31) \\
\hline \multicolumn{5}{|l|}{ Outcome variables } \\
\hline ICU admission before day $+7^{\text {a }}$ (if not yet in ICU) & $4 / 82(5)$ & $4 / 25(16)$ & $9 / 79(11)$ & $1 / 21(5)$ \\
\hline Length of hospital stay after bacteremia onset (median, IQR) & $22(10-38)$ & $13(8-24)$ & $16(8-36)$ & $14(6-30)$ \\
\hline In-hospital mortality & $34 / 130(26)$ & $10 / 36(28)$ & $38 / 104(37)$ & $16 / 27(59)$ \\
\hline
\end{tabular}


This table presents a selection of recorded variables. A full overview is available in Supplementary Table 2.

Abbreviations: ICU, intensive care unit; IQR, interquartile range.

${ }^{a}$ Day 0 is the day of the index blood culture of the ARE/VRE bacteremia episode. 
Table 2. Regression models for 30-day mortality

\begin{tabular}{|c|c|c|c|c|c|c|}
\hline & \multicolumn{3}{|c|}{ Unadjusted models } & \multicolumn{3}{|c|}{ Combined adjusted models } \\
\hline & Combined & Netherlands & Denmark & $\begin{array}{c}\text { Main } \\
\text { analysis }\end{array}$ & $\begin{array}{c}\text { Sensitivity } \\
\text { analysis }\end{array}$ & $\begin{array}{c}\text { Therapy } \\
\text { added }\end{array}$ \\
\hline No of observations & 297 & 166 & 131 & 297 & 295 & 297 \\
\hline No of events & 100 & 47 & 53 & 100 & 99 & 100 \\
\hline No of variables & 1 & 1 & 1 & 5 & 8 & 6 \\
\hline Events to variables & 100 & 47 & 53 & 20 & 12.4 & 16.7 \\
\hline Vancomycin resistance & $1.27(0.87-1.84)$ & $1.16(0.65-2.06)$ & $1.37(0.84-2.25)$ & $1.54(1.06-2.25)$ & $1.49(0.99-2.22)$ & $1.55(1.07-2.26)$ \\
\hline $\begin{array}{l}\text { Inappropriate therapy on } \\
\text { day of index blood culture }\end{array}$ & & & & & & $2.79(0.99-7.86)$ \\
\hline
\end{tabular}

This table presents risk ratios ( $\mathrm{RR}$, with $95 \% \mathrm{CI}$ ) for 30-day mortality for the exposure of interest (vancomycin resistance), with and without adjustment for confounding variables, and with and without the intermediate variable inappropriate therapy on day of index blood culture. In the Supplementary Material, the adjustment procedure is described. Combined models include data from both the Netherlands and Denmark. 
Table 3. Regression models for one-year follow-up for mortality

\begin{tabular}{|c|c|c|c|c|c|}
\hline & \multicolumn{3}{|c|}{ Unadjusted models } & \multicolumn{2}{|c|}{ Combined adjusted models } \\
\hline & Combined & Netherlands & Denmark & $\begin{array}{c}\text { Main } \\
\text { analysis }\end{array}$ & $\begin{array}{c}\text { Sensitivity } \\
\text { analysis }\end{array}$ \\
\hline No of observations & 297 & 166 & 131 & 294 & 297 \\
\hline No of events & 170 & 90 & 80 & 170 & 170 \\
\hline No of variables & 1 & 1 & 1 & 12 & 7 \\
\hline Events to variables & 170 & 90 & 80 & 14.2 & 24.3 \\
\hline Vancomycin resistance & $\mid 1.18(0.84-1.65)$ & $0.91(0.53-1.55)$ & $\mid 1.51(0.97-2.36)$ & $1.25(0.80-1.98)$ & $1.46(0.95-2.25)$ \\
\hline
\end{tabular}

This table presents hazard ratios ( $\mathrm{HR}$, with $95 \% \mathrm{CI})$ for mortality (follow-up of 1 year with censoring) for the exposure of interest (vancomycin resistance), with and without adjustment for confounding variables. In the Supplementary Material, the adjustment procedure is described. Combined models include data from both the Netherlands and Denmark. 
Table 4. Overview of antibiotic therapy for VRE and matched ARE bacteremias

\begin{tabular}{|c|c|c|c|c|c|c|c|c|}
\hline & \multicolumn{4}{|c|}{ End of day $0^{a}$} & \multicolumn{4}{|c|}{ End of day $+3^{a}$} \\
\hline & \multicolumn{2}{|c|}{ ARE } & \multicolumn{2}{|c|}{ VRE } & \multicolumn{2}{|c|}{ ARE } & \multicolumn{2}{|c|}{ VRE } \\
\hline & $\begin{array}{c}\text { NL, } \\
\text { n/N with } \\
\text { data (\%) }\end{array}$ & $\begin{array}{c}\text { DK, } \\
\text { n/N with } \\
\text { data (\%) }\end{array}$ & $\begin{array}{c}\text { NL, } \\
\text { n/N with } \\
\text { data (\%) }\end{array}$ & $\begin{array}{c}\text { DK, } \\
\text { n/N with } \\
\text { data (\%) }\end{array}$ & $\begin{array}{c}\text { NL, } \\
\text { n/N with } \\
\text { data (\%) }\end{array}$ & $\begin{array}{c}\text { DK, } \\
\text { n/N with } \\
\text { data (\%) }\end{array}$ & $\begin{array}{c}\text { NL, } \\
\text { n/N with } \\
\text { data (\%) }\end{array}$ & $\begin{array}{c}\text { DK, } \\
\text { n/N with } \\
\text { data (\%) }\end{array}$ \\
\hline Deceased & $1 / 130(1)$ & $2 / 104(2)$ & $1 / 36(3)$ & $1 / 27(4)$ & $12 / 130(9)$ & 13/104 (12) & $4 / 36(11)$ & $4 / 27(15)$ \\
\hline Censored $^{\mathbf{b}}$ & & & & & $1 / 130(1)$ & & & \\
\hline Discharged & $1 / 130(1)$ & & & $1 / 27(4)$ & $5 / 130(4)$ & $1 / 104(1)$ & $1 / 36(3)$ & $2 / 27(7)$ \\
\hline E. faecium-covering therapy & $10 / 129(8)$ & $5 / 102(5)$ & $13 / 35(37)$ & $7 / 26(27)$ & $76 / 117(65)$ & $82 / 91(90)$ & $20 / 32(62)$ & $22 / 23(96)$ \\
\hline - vancomycin iv & $9 / 129(7)$ & $5 / 102(5)$ & $12 / 35(34)$ & $5 / 26(19)$ & $72 / 117(62)$ & 79/91 (87) & $8 / 32(25)$ & $2 / 23(9)$ \\
\hline - linezolid iv & & & $1 / 35(3)$ & $1 / 26(4)$ & $1 / 117(1)$ & $1 / 91(1)$ & $6 / 32(19)$ & $7 / 23(30)$ \\
\hline - daptomycin iv + linezolid iv & & & & & & & & $10 / 23(43)$ \\
\hline - teicoplanin iv & $1 / 129(1)$ & & & & $2 / 117(2)$ & & $4 / 32(12)$ & \\
\hline - linezolid po & & & & $1 / 26(4)$ & & & $2 / 32(6)$ & $2 / 23(9)$ \\
\hline - daptomycin iv & & & & & & $2 / 91(2)$ & & \\
\hline - vancomycin intrathecally & & & & & $1 / 117(1)$ & & & \\
\hline - linezolid iv + tigecyclin iv & & & & & & & & $1 / 23(4)$ \\
\hline Appropriate therapy & $10 / 129(8)$ & $5 / 102(5)$ & $1 / 35(3)$ & $2 / 26(8)$ & 76/117 (65) & $82 / 91(90)$ & $12 / 32(38)$ & $20 / 23(87)$ \\
\hline $\begin{array}{l}\text { Appropriate therapy or } \\
\text { central line removed }\end{array}$ & $12 / 129(9)$ & $5 / 102(5)$ & $2 / 35(6)$ & $2 / 26(8)$ & $76 / 117(65)$ & $82 / 91(90)$ & $12 / 32(38)$ & $20 / 23(87)$ \\
\hline
\end{tabular}

Abbreviations: DK, Denmark; iv, intravenously; NL, Netherlands; po, orally. 
${ }^{a}$ Day 0 is the day of the index blood culture of the ARE/VRE bacteremia episode.

${ }^{\mathrm{b}}$ One Dutch patient with ARE bacteremia was censored for the assessment of antibiotic therapy (not for mortality) due to transfer to another hospital. 
Table 5. Regression models for 30-day mortality evaluating appropriateness of therapy

\begin{tabular}{|c|c|c|c|}
\hline & \multicolumn{3}{|c|}{ Baseline after day ... } \\
\hline & $\mathbf{0}$ & +1 & +2 \\
\hline & \multicolumn{3}{|c|}{ Unadjusted models } \\
\hline No of observations & 289 & 283 & 274 \\
\hline No of events & 95 & 88 & 80 \\
\hline ARE - on inappropriate therapy & Reference & Reference & Reference \\
\hline ARE - on appropriate therapy & $0.41(0.10-1.74)$ & $0.82(0.45-1.51)$ & $1.01(0.57-1.79)$ \\
\hline VRE - on inappropriate therapy & $1.24(0.82-1.85)$ & $1.15(0.71-1.88)$ & $1.40(0.73-2.70)$ \\
\hline \multirow[t]{2}{*}{ VRE - on appropriate therapy } & NA & $1.53(0.68-3.46)$ & $1.32(0.64-2.71)$ \\
\hline & \multicolumn{3}{|c|}{ Adjusted models - main analysis } \\
\hline No of observations & 289 & 276 & 268 \\
\hline No of events & 95 & 87 & 80 \\
\hline No of variables & 9 & 14 & 14 \\
\hline Events to variables & 10.6 & 6.2 & 5.7 \\
\hline ARE - on inappropriate therapy & Reference & Reference & Reference \\
\hline ARE - on appropriate therapy & $0.33(0.08-1.40)$ & $0.79(0.43-1.45)$ & $0.82(0.47-1.43)$ \\
\hline VRE - on inappropriate therapy & 1.69 (1.09-2.61) & $2.01(1.13-3.57)$ & $2.43(0.94-6.33)$ \\
\hline \multirow[t]{2}{*}{ VRE - on appropriate therapy } & NA & $5.79(1.43-23.40)$ & $1.73(0.83-3.61)$ \\
\hline & \multicolumn{3}{|c|}{ Adjusted models - sensitivity analysis } \\
\hline No of observations & 285 & 278 & 270 \\
\hline No of events & 94 & 87 & 80 \\
\hline No of variables & 16 & 17 & 15 \\
\hline Events to variables & 5.9 & 5.1 & 5.3 \\
\hline ARE - on inappropriate therapy & Reference & Reference & Reference \\
\hline ARE - on appropriate therapy & $0.31(0.08-1.13)$ & $0.69(0.38-1.28)$ & $0.88(0.42-1.84)$ \\
\hline VRE - on inappropriate therapy & $1.42(0.79-2.55)$ & $1.81(0.99-3.31)$ & $2.38(0.99-5.74)$ \\
\hline VRE - on appropriate therapy & NA & $2.60(0.55-12.32)$ & $2.12(0.88-5.09)$ \\
\hline
\end{tabular}

This table presents risk ratios $(\mathrm{RR}$, with $95 \% \mathrm{CI})$ for 30 -day mortality for the interaction between vancomycin resistance and appropriateness of therapy. The baseline for these models is positioned on three different moments, namely the end of the day of the index blood culture 
medRxiv preprint doi: https://doi.org/10.1101/2020.05.10.20049783; this version posted May 15, 2020. The copyright holder for this preprint (which was not certified by peer review) is the author/funder, who has granted medRxiv a license to display the preprint in perpetuity.

It is made available under a CC-BY-NC 4.0 International license .

(day 0$)$, the end of the day after (day +1$)$, and the end of the day thereafter (day +2$)$. This

implies that separately for each baseline, patients having died (or censored, as antibiotic therapy

could not be fully assessed) before this moment were removed from the dataset.

Appropriateness of therapy refers to the antibiotic therapy provided at baseline. RRs are

presented with and without adjustment for confounding variables. In the Supplementary

Material, the adjustment procedure is described. All models include data from both the

Netherlands and Denmark. 
Figure 1. One-year survival curve for VRE and matched ARE bacteremias

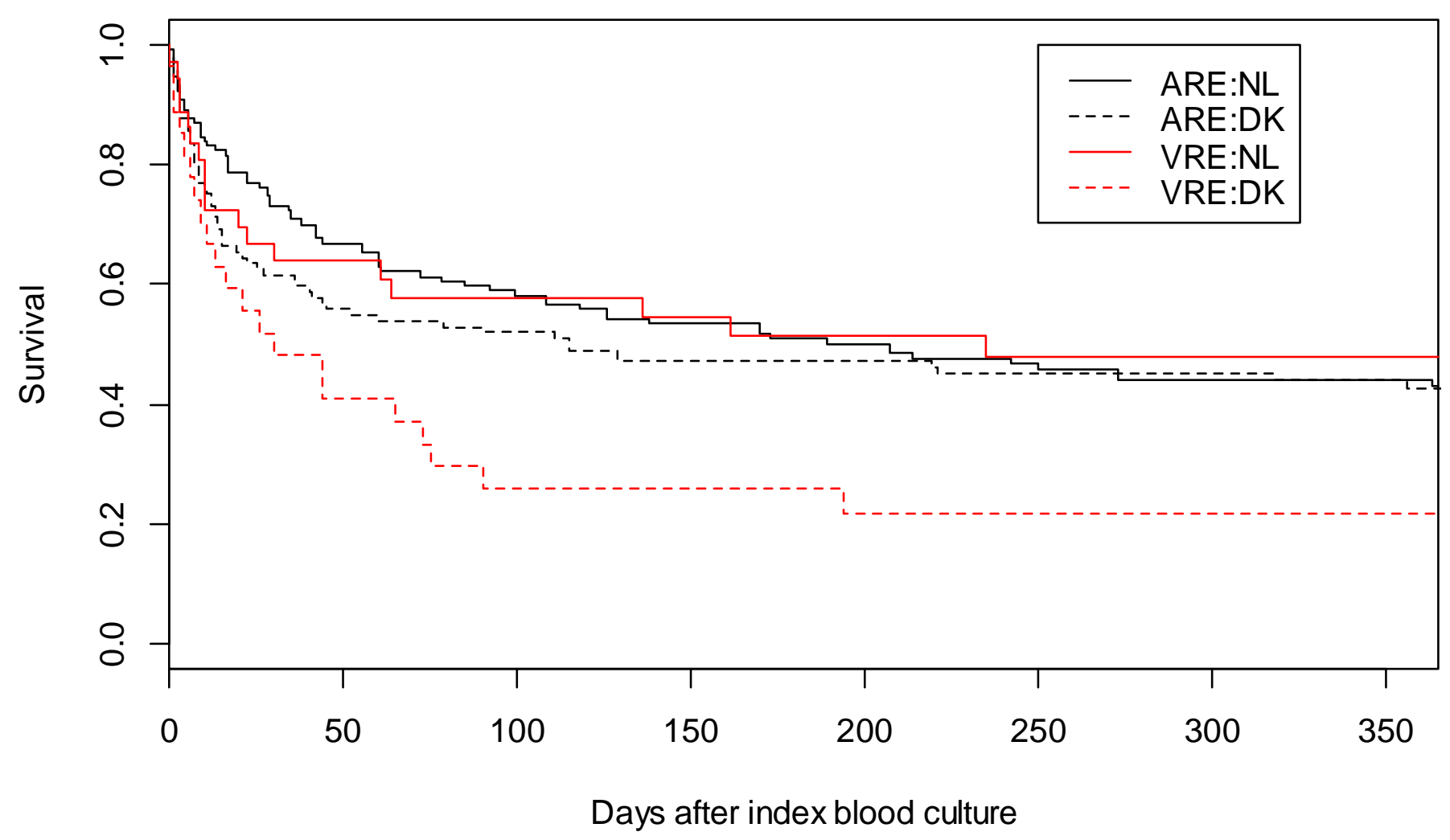

Kaplan-Meier plot indicating one-year survival after ARE/VRE bacteremia, stratified on vancomycin resistance and country.

Abbreviations: NL, Netherlands, DK, Denmark. 
Figure 2. Time to Enterococcus faecium-covering antibiotic therapy for VRE and matched ARE bacteremias

\section{Netherlands}

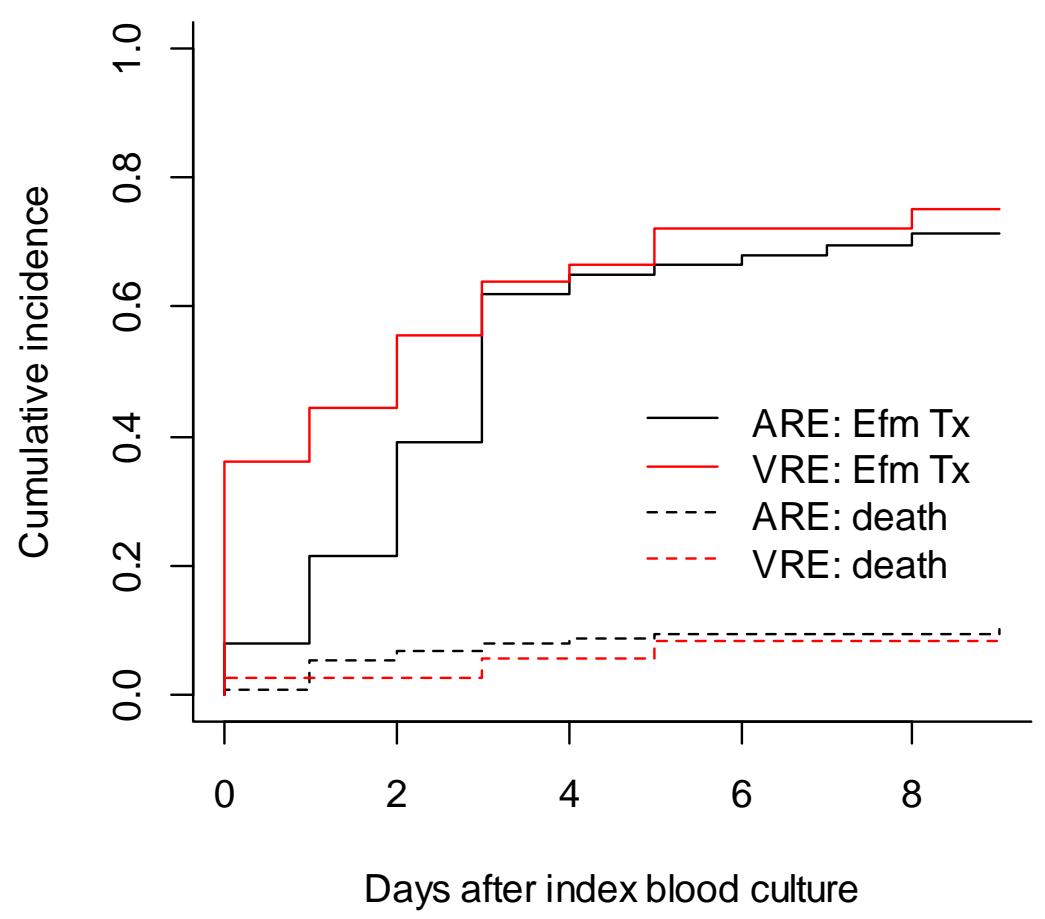

Denmark

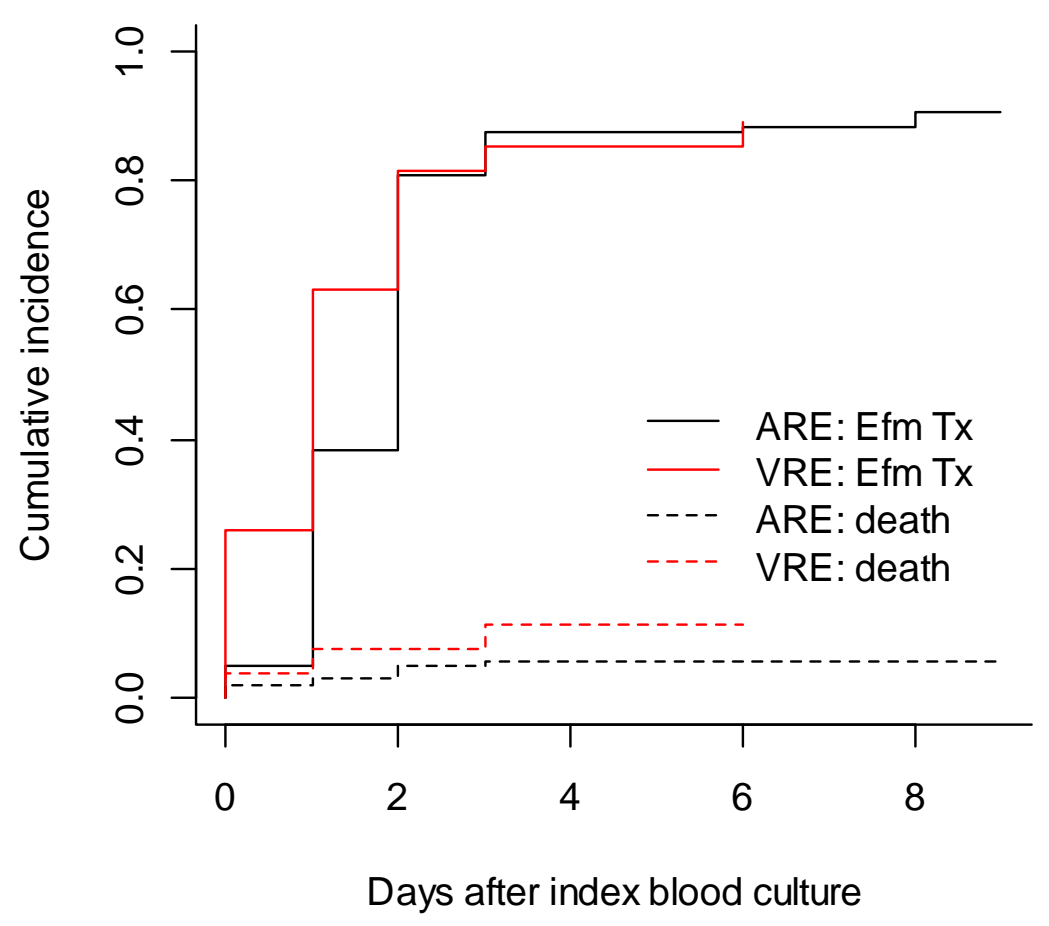

Cumulative incidence plots of initiation of $E$. faecium-covering antibiotic therapy after onset of bacteremia and its competing risk mortality before onset of $E$. faecium-covering antibiotic therapy, stratified on vancomycin resistance.

Abbreviations: Efm Tx, Enterococcus faecium-covering therapy. 
Figure 3. Time to appropriate antibiotic therapy for VRE and matched ARE bacteremias

\section{Netherlands}

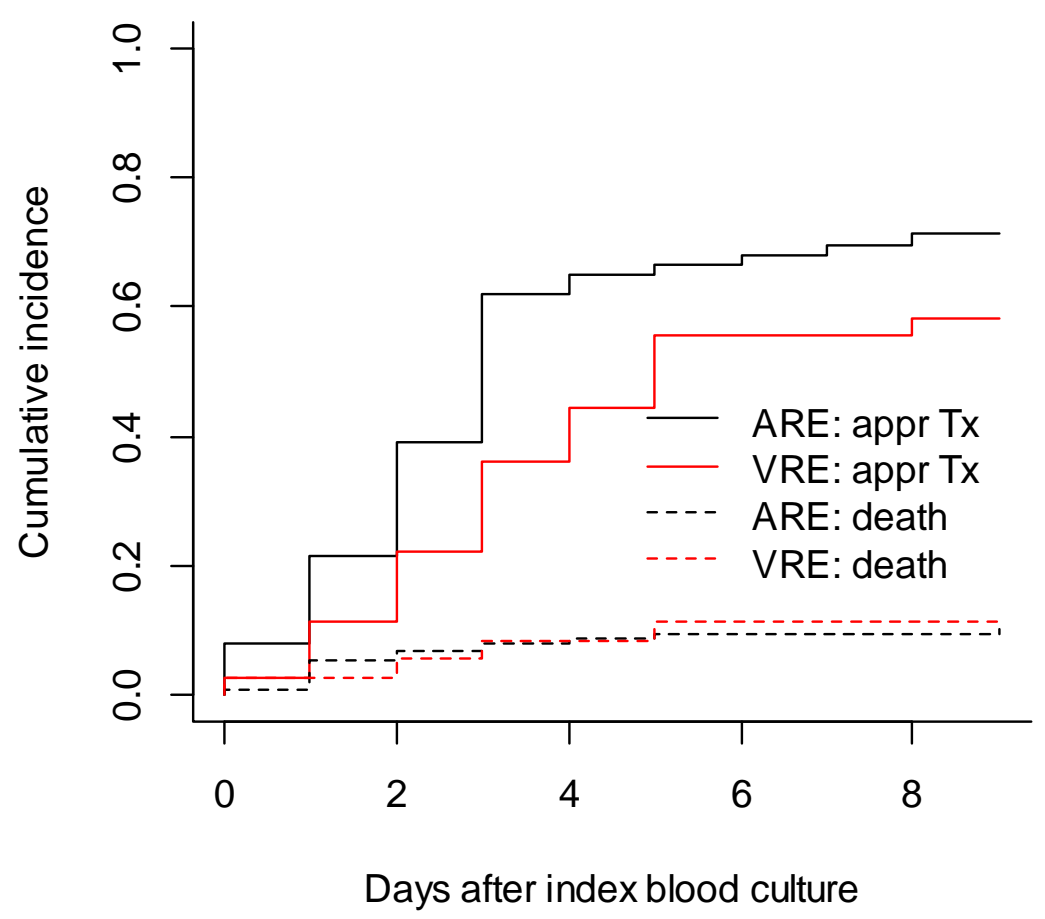

Denmark

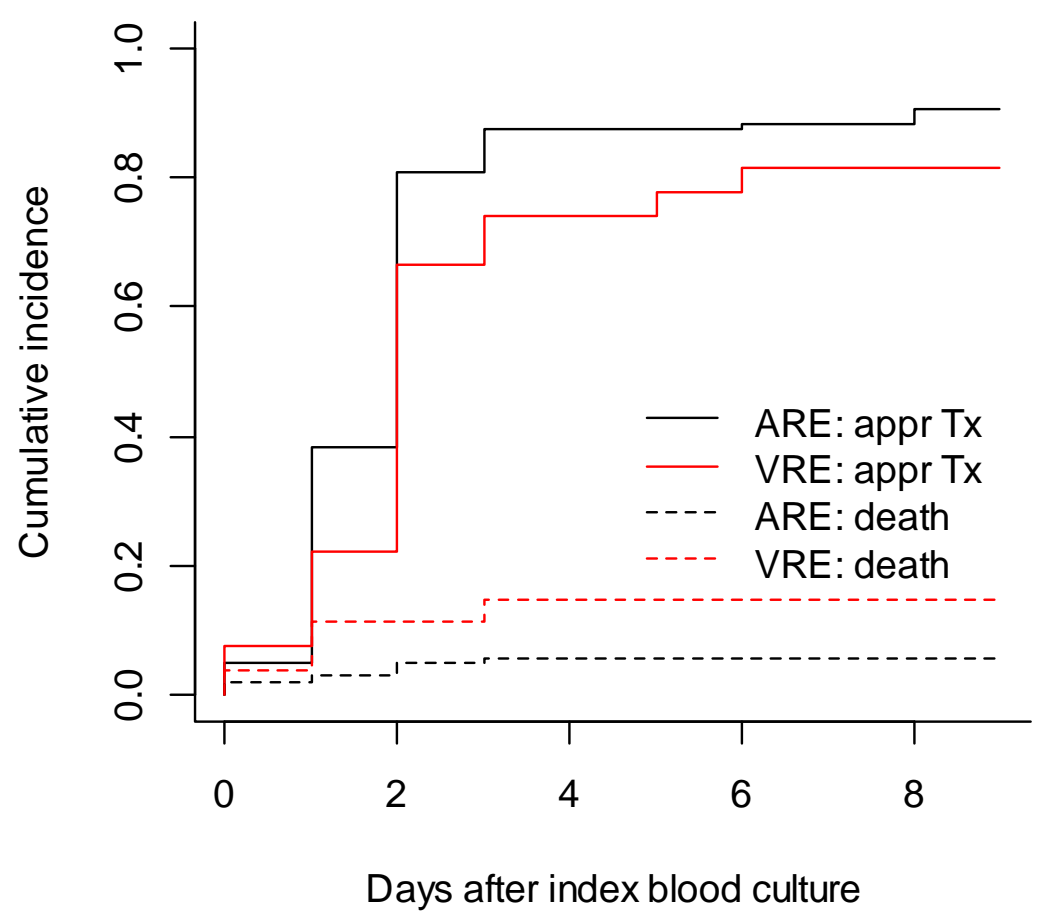

Cumulative incidence plots of initiation of appropriate antibiotic therapy after onset of bacteremia and its competing risk mortality before onset of appropriate antibiotic therapy, stratified on vancomycin resistance.

Abbreviations: appr Tx, appropriate therapy. 